\title{
Australian Journal of Crop Science \\ Effects of seed size and sowing depth in the emergence and morphophysiological development of soybean cultivated in sandy texture soil
}

\author{
Arnaldo Cintra Limede, Carlos Eduardo da Silva Oliveira, André Zoz, Alan Mario Zuffo*, Fábio Steiner, \\ Tiago Zoz
}

\author{
Department of Crop Production, State University of Mato Grosso do Sul, 79540-000, Cassilândia, Mato Grosso do \\ Sul, Brazil
}

\section{*Corresponding author: alan_zuffo@hotmail.com}

\begin{abstract}
Seed size and sowing depth are important factors for an adequate plant stand in soybean crops. This study aimed at assessing the emergence and morphological development of soybean plants, affected by seed size and sowing depth in sandy texture soil. The trial was carried out in a greenhouse with an experimental design of randomized blocks, organized in the factorial scheme $3 \times 3$. The factors were seed size (sieves 6.0,6.5, and $7.0 \mathrm{~mm}$ ) and sowing depth $(2.0,4.0$, and $6.0 \mathrm{~cm}$ ) with four replications. We assessed the emergence, emergence speed index, mean time of emergence, number of leaves per plant, stem diameter, plant height, dry mass of leaves, dry mass of stem, dry mass of root system, dry mass of shoot, total dry mass of plant, leaf area, root system volume, root system density, shoot/root ratio, ratio of leaf area, and ratio of leaf dry mass. The seed size does not influence the emergence of soybean seedlings; however, the seeds of sieve $7.0 \mathrm{~mm}$ produce plants with a higher dry mass of stem, dry mass of shoot, and root system volume. The soybean sowing at $4.0 \mathrm{~cm}$ depth resulted in the highest morphological development.
\end{abstract}

Keywords: Glycine max L. Merrill, emergence, vigor

Abbreviations: DAE_days after emergence; EMER_emergence rate; MET_mean emergence time; ESI_emergence speed index; PH_plant height; SDI_stem diameter; NLV_number of leaves per plant; LA_leaf area; LDM_leaves dry matter; STDM_stem dry matter; CHLO_relative chlorophyll index; RSDM_root system dry matter; SDM_shoot dry matter; TDM_total dry matter; RSV_root system volume; RSD_root system density; SRR_shoot root ratio; LAR_leaf area ratio; SLA_specific leaf area; LMR_leaf matter ratio.

\section{Introduction}

The soybean is an important commodity with diverse uses, from animal feed to biodiesel production. In Brazil, the soybean crop is the largest source of edible oil, and it is an essential ingredient in the animal diet (FAO, 2017). Due to its economic importance, the soybean has been cultivated in marginal regions, whose soils are of sandy texture. This practice is common among producers because the price of the land in these regions is lower when compared to areas where agriculture is already consolidated. However, much basic information needs to be clearly defined to grow soybeans in these regions, including adequate sowing depth and seed size.

The final yield of a crop is directly linked to sowing and the adequate formation of stands, and the depth of seed deposition is a factor that is directly related to the success of this process (Pacheco et al., 2010). According to Souza and Weirich Neto (2015), two factors make it difficult to define the ideal depth of soybean sowing: the first is the germination of the epigeal type that the species presents, and the second is the difficulty in accurately estimating the hypocotyl size of the seedling.

The physical characteristics of the soil also make it difficult to determine the ideal seeding depth (Zuo et al., 2017). A sowing depth deeper than $5 \mathrm{~cm}$ may decrease the emergence, mainly in sandy soils (EMBRAPA, 2011). However, superficial seeding predisposes seeds to environmental variations, such as water or thermal excess or deficiency, which may culminate in small and less vigorous seedlings (Tillmann et al., 1994).

Seed size is another relevant factor that influences the stand formation (MANDAL et al., 2008). According to Bezerra et al. (2016), the larger seeds present larger amounts of the reserve, resulting in a higher probability of success in the formation of the stand in unfavorable environmental conditions. In a study by Padua et al. (2010), the authors verified that in the same progeny, larger seeds increased seedling germination and vigor.

Some studies have shown that soybean seeds of larger size, when compared to smaller ones, have superior physiological quality (Padua et al., 2010; Vinhal-Freitas et al., 2011). However, these results are not unanimous (Camozzato et al., 2009, Piccinin et al., 2012). For Kopper et al. (2010), the small seeds have a higher surface/volume ratio than the large ones, which facilitates the obtaining of water to initiate the germination process. However, they present fewer reserves. Seed size may influence seedling emergence when sown deeper (Roy et al., 1996). This fact correlates with the soil moisture level, and the amount of 
water absorbed to complete the seedling emergence depends on each seed size (Kering and Zang, 2015).

Considering the above, studies with sowing depth and seed size in soils of sandy textures are necessary. The objective was to evaluate the emergence and morphophysiological development of soybean plants, as a function of seed size and sowing depth in soil with a sandy texture.

\section{Results and Discussion}

\section{Effect of treatments on variables}

Stem dry matter, shoot dry matter, root system volume, root system density, and specific leaf area were influenced by seed size, and the other variables were not influenced by sieve sizes (Table 2). The size of the soybean seed does not influence the percentage and the rate of emergence speed, but it affects the growth of the plant during its season. These results are similar, in part, to those obtained by Barbosa et al. (2010), who did not verify seed size influence in soybean emergence; however, a significant effect was observed in the rate of emergence. Such differences may be related to the climatic conditions of each region where the studies were carried out.

\section{Effect of seed sizes on plant growth and development}

There was a significant effect of the sowing depth on the emergence rate, mean emergence time, emergence speed index, plant height, leaf area, leaf dry matter, stem dry matter, shoot dry matter, total dry matter, specific leaf area, and leaf area ratio (Table 2). These results are similar to those obtained by Aisenbeg et al. (2014), who also verified a significant effect of sowing depth on emergence and morphological characteristics of soybean.

There was no verified significant interaction between seed size and sowing depth for any evaluated variables (Table 2). That indicates that the responses to the sowing depth are similar for the evaluated seed sizes.

The highest means observed for stem dry matter, shoot dry matter, and root system volume was in the soybean seeds with 6.5 and $7.0 \mathrm{~mm}$ (Table 3). These results are similar to those obtained by Vinhal-Freitas et al. (2011), who evaluated the influence of seed size (sieves: 5.0, 5.5, 6.0, and $7.0 \mathrm{~mm}$ ) on the germination and vigor of soybean seeds. The authors verified that seeds with $7.0 \mathrm{~mm}$ presented higher physiological quality in the tests of accelerated aging, electrical conductivity, fresh and dry matter; however, the size of soybean seeds did not influence germination and seedling length.

According to Carvalho and Nakagawa (2000), seed size should not influence germination, since this process depends on other factors such as viability and environmental conditions. The authors also report that seeds of larger size give rise to more vigorous seedlings and, under variable field conditions, may result in higher stands.

Although it was not observed the effect of seed size on the emergence rate and the emergence speed index, the larger seeds gave origin to the plants with larger shoot matter. This result is because the larger seeds have more developed embryos (Carvalho and Nakagawa, 2000). Also, it is important to highlight that larger seeds have a greater amount of reserve to meet the demands of growing seedlings, providing higher growth when compared to smaller seeds (Pádua et al., 2010).

For the root system volume, there was no difference between the means of the seeds with 6.5 and $7.0 \mathrm{~mm}$; however, its means were higher than the seeds with $6.0 \mathrm{~mm}$ (Table 3). The root system density of the seeds with $6.0 \mathrm{~mm}$ was around $24 \%$ greater than the mean of seeds with 6.5 and $7.0 \mathrm{~mm}$ (Table 3). The highest root system density verified for seeds with $6.0 \mathrm{~mm}$ is because there was no difference between the seed sizes for the root system dry matter, and the seeds with 6.5 and $7.0 \mathrm{~mm}$ presented a higher mean of root system volume. The root system density is estimated from the root division of the root system by the root system volume, so, it will be observed higher density values in the seeds with a smaller root system volume.

Plants produced from the seeds with $7.0 \mathrm{~mm}$ had a smaller specific leaf area; in other words, they had thicker leaves (Table 3). Based on this information, it is possible to affirm that plants produced from seeds with $7.0 \mathrm{~mm}$ have leaves with a greater amount of reserve. The largest amount of reserve of these seeds promoted a more accentuated growth of the plants.

\section{Effect of sowing depth in the growth and development the plants}

The soybean sowing at $6.0 \mathrm{~cm}$ depth resulted in the lowest mean values of emergence rate, emergence speed index (ESI), plant height, stem dry matter, total dry matter, and longer mean emergence time (Table 4). These results are similar to those reported by Aisenberg et al. (2014), who observed inhibitions on emergence rate, emergence speed index, and stem dry matter in soybean seedlings in sowing with $6.0 \mathrm{~cm}$ depth.

Sowing with $6.0 \mathrm{~cm}$ depth reduced and delayed the emergence due to the greater physical impediment provided by the soil to the seedlings (Modolo et al., 2010). Therefore, when the soybean seeds are sown deeper, there is more energy expenditure for the hypocotyl to break the layer above the seed. Excessive depths affect the germination, emergence, and development of the plant, mainly due to the decrease in temperature and the availability of $\mathrm{O}_{2}$ and, consequently, higher accumulation of $\mathrm{CO}_{2}$ (Tillmann et al., 1994; Prado et al., 2002).

It is important to emphasize that the plants that emerge first tend to grow more and get more biomass due to photosynthesis in the early stages of growth, except under stressful conditions (Zuffo et al., 2016). The seeds deposited at depths of 2.0 and $4.0 \mathrm{~cm}$ emerged before the seeds deposited at a depth of $6.0 \mathrm{~cm}$, which culminated in higher biomass accumulation, verified by the total dry mass of plant. Sowing at $4.0 \mathrm{~cm}$ depth provided plants with higher means for leaf area and leaf dry matter when compared to those sown at $2.0 \mathrm{~cm}$ and $6.0 \mathrm{~cm}$ (Table 4). These results are different from those observed by Aisenberg et al. (2014), who verified that soybean seeds with depths below $3.0 \mathrm{~cm}$ inhibit the leaf area.

Soybean seeds deposited at 4.0 and $6.0 \mathrm{~cm}$ depth resulted in plants with greater specific leaf area and leaf matter ratio (Table 4). The leaf area ratio indirectly indicates the leaf area that is useful for photosynthesis (Bennicasa, 2003). Therefore, although the seeds deposited at 4.0 and $6.0 \mathrm{~cm}$ 
Table 1. Water content and 1,000 seeds weight of soybean with different sizes.

\begin{tabular}{lcc}
\hline Seed size & Water content & 1,000 seeds weight \\
\hline Sieve $(\mathrm{mm})$ & $\%$ & $\mathrm{~g}$ \\
6.0 & 4.59 & 13.86 \\
6.5 & 5.11 & 16.57 \\
7.0 & 5.66 & 19.90 \\
\hline
\end{tabular}

Table 2. Analysis of variance (F value) of morphophysiological traits of soybean (cv. NS 5559) in sowing depth and seed size. Cassilândia, Mato Grosso do Sul, Brazil. 2016/2017.

\begin{tabular}{|c|c|c|c|c|c|}
\hline Sources of variation & EMER & MET & ESI & $\mathrm{PH}$ & SDI \\
\hline Seed size (SS) & 1.21 & 0.41 & 1.30 & 0.16 & 2.73 \\
\hline Sowing depth (DP) & $3.85^{*}$ & $17.81 * *$ & $12.39 * *$ & $3.20 *$ & 1.50 \\
\hline$S S \times D P$ & 1.14 & 0.61 & 0.95 & 1.65 & 0.31 \\
\hline \multirow[t]{2}{*}{ C.V. (\%) } & 11.74 & 7.22 & 14.35 & 12.57 & 5.76 \\
\hline & NLV & LA & LDM & STDM & $\mathrm{CHLO}$ \\
\hline Seed size (SS) & 0.12 & 1.36 & 2.00 & $3.92^{*}$ & 0.01 \\
\hline Sowing depth (DP) & 2.14 & $5.38^{*}$ & $4.76^{*}$ & $3.71 *$ & 2.16 \\
\hline$S S \times D P$ & 0.62 & 0.18 & 0.12 & 0.90 & 0.43 \\
\hline \multirow[t]{2}{*}{ C.V. (\%) } & 11.8 & 11.72 & 12.6 & 13.58 & 5.95 \\
\hline & RSDM & SDM & TDM & RSV & RSD \\
\hline Seed size (SS) & 0.27 & $3.17^{*}$ & 0.76 & $3.19 *$ & $5.76^{*}$ \\
\hline Sowing depth (DP) & 0.99 & $4.80^{*}$ & $3.47^{*}$ & 0.80 & 1.00 \\
\hline SS $\times$ DP & 0.23 & 0.12 & 0.15 & 0.27 & 0.18 \\
\hline \multirow[t]{2}{*}{ C.V. (\%) } & 15.91 & 11.93 & 11.36 & 11.23 & 10.93 \\
\hline & SRR & LAR & \multicolumn{2}{|c|}{ SLA } & LMR \\
\hline Seed size (SS) & 2.83 & $4.92 *$ & \multicolumn{2}{|c|}{1.57} & 1.68 \\
\hline Sowing depth (DP) & 1.67 & $3.02 *$ & \multicolumn{2}{|c|}{$3.58^{*}$} & 2.31 \\
\hline$S S \times D P$ & 0.21 & 0.92 & \multicolumn{2}{|c|}{1.91} & 1.93 \\
\hline C.V. (\%) & 15.66 & 2.83 & \multicolumn{2}{|c|}{6.6} & 6.11 \\
\hline
\end{tabular}

Table 3. Morphophysiological traits of soybean (cv. NS 5559) plants originated from seeds with different sizes. Cassilândia, Mato Grosso do Sul, Brazil. 2016/2017.

\begin{tabular}{|c|c|c|c|c|c|c|}
\hline Seed size & EMER & MET & ESI & & $\mathrm{PH}$ & SDI \\
\hline Sieve $(\mathrm{mm})$ & $\%$ & days & - & & $\mathrm{cm}$ & $\mathrm{mm}$ \\
\hline 6.0 & 70.00 & 7.57 & 1.04 & & 60.23 & 4.58 \\
\hline 6.5 & 75.83 & 7.59 & 1.15 & & 59.95 & 4.49 \\
\hline \multirow[t]{3}{*}{7.0} & 65.83 & 7.95 & 0.97 & & 62.99 & 4.98 \\
\hline & NLV & LA & LDM & & STDM & CHLO \\
\hline & $\mathrm{n}$ o plant $^{-1}$ & $\mathrm{dm}^{2}$ plant $^{-1}$ & $---g p$ & $n \mathrm{nt}^{-1}---$ & & IRC \\
\hline 6.0 & 8.00 & 4.04 & 1.59 & & $1.20 \mathrm{~b}$ & 26.18 \\
\hline 6.5 & 8.33 & 4.64 & 1.84 & & $1.31 \mathrm{ab}$ & 26.04 \\
\hline \multirow[t]{3}{*}{7.0} & 8.42 & 4.66 & 1.96 & & $1.60 \mathrm{a}$ & 26.07 \\
\hline & RSDM & SDM & TDM & & RSV & RSD \\
\hline & \multicolumn{4}{|c|}{------------- g plant $^{-1}$------------ } & $\mathrm{cm}^{3}$ plant $^{-1}$ & $\mathrm{~g} \mathrm{~cm}^{-3}$ \\
\hline 6.0 & 2.02 & $2.80 \mathrm{~b}$ & 4.82 & & $11.67 \mathrm{~b}$ & $0.17 \mathrm{a}$ \\
\hline 6.5 & 1.91 & $3.16 \mathrm{ab}$ & 5.06 & & $14.50 \mathrm{a}$ & $0.13 \mathrm{~b}$ \\
\hline \multirow[t]{3}{*}{7.0} & 1.78 & $3.56 \mathrm{a}$ & 5.34 & & $14.33 \mathrm{a}$ & $0.13 \mathrm{~b}$ \\
\hline & SRR & LAR & & SLA & & LMR \\
\hline & $\mathrm{g} \mathrm{g}^{-1}$ & \multicolumn{3}{|c|}{--- $\mathrm{dm}^{2} \mathrm{~g}^{-1}$} & \multicolumn{2}{|r|}{$\mathrm{g} \mathrm{g}^{-1}$} \\
\hline 6.0 & 1.52 & \multicolumn{2}{|c|}{$2.57 \mathrm{a}$} & 0.86 & \multicolumn{2}{|r|}{0.33} \\
\hline 6.5 & 1.72 & \multicolumn{2}{|l|}{$2.57 \mathrm{a}$} & 0.93 & \multicolumn{2}{|r|}{0.36} \\
\hline 7.0 & 2.03 & \multicolumn{2}{|l|}{$2.41 \mathrm{~b}$} & 0.86 & \multicolumn{2}{|r|}{0.36} \\
\hline
\end{tabular}

Means followed by a different letter are statistically different by LSD test at 5\% probability. EMER - emergence rate, MET - mean emergence time, ESI - emergence speed index, PH - plant height, SDI - stem diameter, NLV - number of leaves per plant, LA - leaf area, LDM - leaves dry matter, STDM - stem dry matter, CHLO - relative chlorophyll index, RSDM - root system dry matter, SDM - shoot dry matter, TDM - total dry matter, RSV - root system volume, RSD - root system density, SRR - shootroot ratio, LAR - leaf area ratio, SLA - specific leaf area, LMR - leaf matter ratio. 
Table 4. Morphophysiological traits of soybean (cv. NS 5559) sown at different depths. Cassilândia, Mato Grosso do Sul, Brazil. 2016/2017.

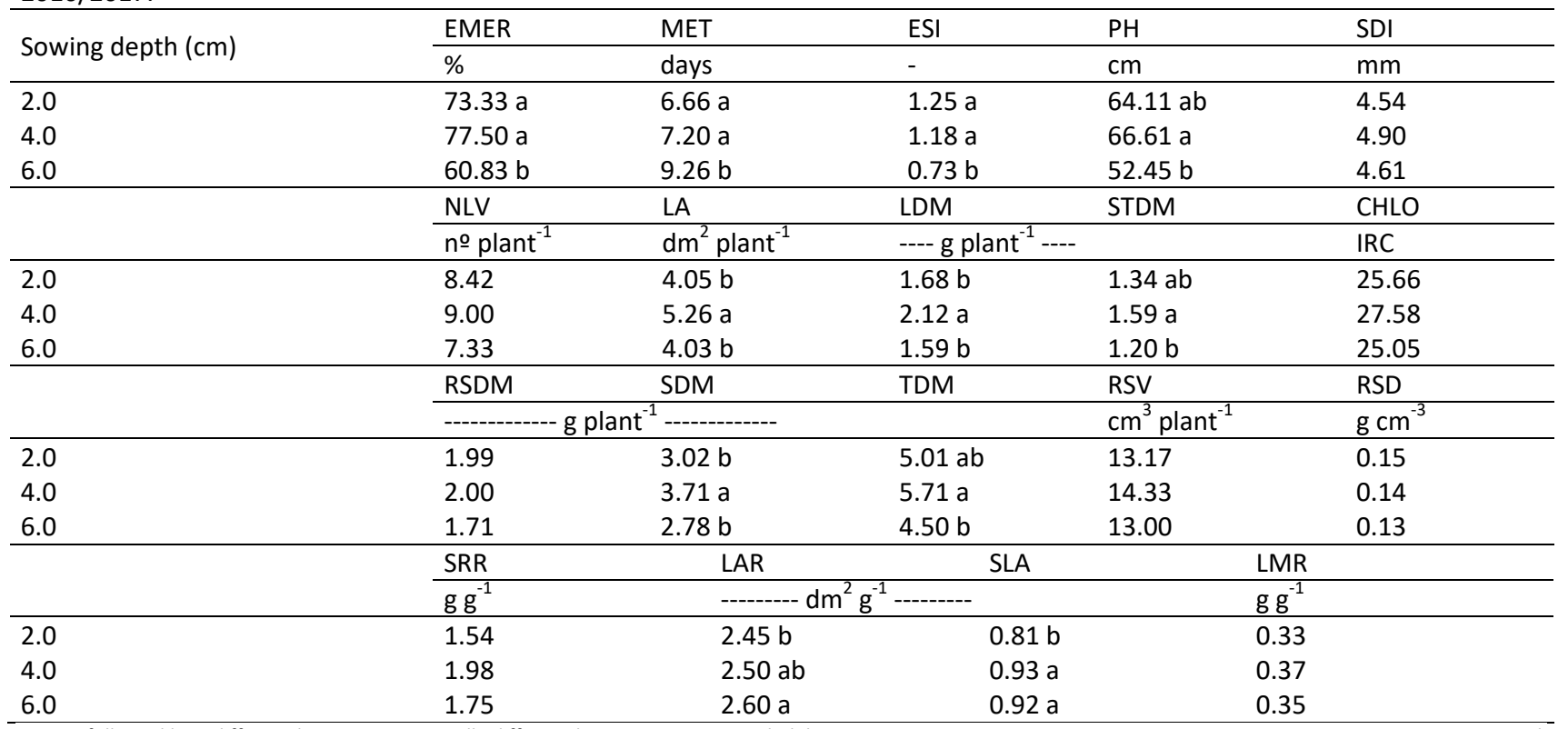

Means followed by a different letter are statistically different by LSD test at 5\% probability. EMER - emergence rate, MET - mean emergence time, ESI - emergence speed index, PH - plant height, SDI - stem diameter, NLV - number of leaves per plant, LA - leaf area, LDM - leaves dry matter, STDM - stem dry matter, CHLO - relative chlorophyll index, RSDM - root system dry matter, SDM - shoot dry matter, TDM - total dry matter, RSV - root system volume, RSD - root system density, SRR - shootroot ratio, LAR - leaf area ratio, SLA - specific leaf area, LMR - leaf matter ratio.

depth results in plants with greater leaf area for photosynthesis when checking the total dry mass, only the sowing with $4.0 \mathrm{~cm}$ depth culminated in plants with a higher value for this variable. From an economic point of view, the grain yield is more important than the total dry matter. However, the grain yield of crops such as corn and soybean is closely linked to photosynthetic efficiency in the transformation of intercepted solar radiation into dry matter (Casaroli et al., 2007), which depends heavily on the leaf area and the number of nodes (Alcântara Neto et al., 2011). In the present study, the soybean yield has not been evaluated, but, because of the effects of sowing depth on the morphophysiological characteristics. It can be inferred the sowing at $4.0 \mathrm{~cm}$ depth in sandy soils may result in higher soybean yield.

\section{Materials and Methods}

\section{Location and experimental characterization}

The trial was run in a greenhouse at The State University of Mato Grosso do Sul, Unit of Cassilandia, in Cassilandia, MS (Latitude 19o 07 '21 "S, Longitude 51ㅇ 43'15" W and Altitude of $510 \mathrm{~m}$ ).

The regional climate according to the Köppen classification is Aw, characterized as a tropical climate with hot summers and a tendency towards high rainfall levels, dry winters, and a dry season between May and September. The temperature and relative humidity were monitored daily in the greenhouse with the aid of an automatic weather station (CASSILANDIA-A742), during the experiment period (from August 31 to October 26, 2016). The environmental conditions during the trial run were: average air temperature: $23.71 \stackrel{\circ}{\circ}$, and average relative humidity: $56.6 \%$.

The soil used was Arenic Entisol, and was collected in the layer from 0.0 to $20.0 \mathrm{~cm}$ depth. Its chemical traits were analyzed following the procedure by Embrapa (2009). The results of the chemical analysis were: $\mathrm{pH}\left(\mathrm{CaCl}_{2}\right): 5.4 ; 0 . \mathrm{M}$.: $14.0 \mathrm{~g} \mathrm{dm}^{-3}$; P (resin): $2.0 \mathrm{mg} \mathrm{dm}{ }^{-3} ; \mathrm{K}$ (Melich-I): $1.11 \mathrm{cmol}_{\mathrm{c}}$ $\mathrm{dm}^{-3}$; Ca (KCl): $10.0 \mathrm{cmol}_{\mathrm{c}} \mathrm{dm}^{-3}$; $\mathrm{Mg}(\mathrm{KCl}): 7.0 ; \mathrm{H}+\mathrm{Al}: 22.0$ $\mathrm{cmol}_{\mathrm{c}} \mathrm{dm}^{-3}$; Al: $0.0 \mathrm{cmol}_{\mathrm{c}} \mathrm{dm}^{-3}$; V: $46.0 \%$; S-SO $\mathrm{SO}_{4}: 2.0 \mathrm{mg} \mathrm{dm}^{-3}$; B: $0.08 \mathrm{mg} \mathrm{dm}^{-3}$; Cu: $0.60 \mathrm{mg} \mathrm{dm}^{-3}$; Fe: $8.00 \mathrm{mg} \mathrm{dm}^{-3}$; Mn: $5.70 \mathrm{mg} \mathrm{dm}^{-3}$, and $\mathrm{Zn}: 0.30 \mathrm{mg} \mathrm{dm}^{-3}$. The results of the physical analysis were: clay: $95 \mathrm{~g} \mathrm{~kg}^{-1}$, silt: $50 \mathrm{~g} \mathrm{~kg}^{-1}$, and sand: $855 \mathrm{~g} \mathrm{~kg}^{-1}$.

\section{Experimental design}

The experimental design was a randomized block with four replicates, in a $3 \times 3$ factorial scheme. The factors were three seed sizes (sieves 6.0,6.5, and $7.0 \mathrm{~mm}$ ) and three sowing depths $(2.0,4.0$, and $6.0 \mathrm{~cm})$. The seeds were classified in sets of sieves with different diameters. A physical seed characterization was performed, and the results are presented in Table 1.

\section{Experimental procedure}

Each experimental unit consisted of a plastic pot with 12 $\mathrm{dm}^{3}$. Wood segments with $1.5 \mathrm{~cm}$ diameter and 2.0, 4.0, and $6.0 \mathrm{~cm}$ length were made to get the seeding depth. Before sowing, the pots were irrigated and were made ten holes according to the depths predetermined in each treatment. One seed was deposited per hole, resulting ten seeds per pot. Soybean cultivar NS 5559 IPRO was used with medium size, indeterminate growth habit, a season of 100 to 110 days, and maturation group 5.9.

The seedlings emerged were counted daily, and when was verified stabilization of the emergence, thinning was done, leaving only one plant per pot. The water content of the soil was monitored daily and kept close to the total soil water retention capacity with daily watering. 
At 15 days after emergence (DAE), $75 \mathrm{mg} \mathrm{dm}^{-3}$ of nitrogen, $300 \mathrm{mg} \mathrm{dm}^{-3}$ of phosphorus $\left(\mathrm{P}_{2} \mathrm{O}_{5}\right)$ and $150 \mathrm{mg} \mathrm{dm}^{-3}$ of potassium $\left(\mathrm{K}_{2} \mathrm{O}\right)$ were applied. The fertilizers were diluted in water and applied via irrigation water.

\section{Traits measured}

After sowing, the seedlings emerged in each pot were counted daily, and from the data obtained the following were estimated:

a) Emergence rate (\%): obtained by counting the number of seedlings that emerged after the stabilization of the stand. It was considered to be an emerged seedling when the cotyledon was above ground.

b) Emergence speed index (ESI): estimated by the equation proposed by Maguire (1962):

$E S I=N 1 / D 1+N 2 / D 2+\ldots N n / D n$

$\mathrm{N} 1=$ number of emerged seedlings in the first day;

$\mathrm{Nn}=$ accumulated number of emerged seedlings;

D1= first day of counting;

$\mathrm{Dn}=$ number of days counted after sowing.

c) Mean emergence time (MET - days): estimated by the equation proposed by Labouriau (1983):

$\mathrm{MET}=(\Sigma \mathrm{Ni} \times \mathrm{Ti}) / \Sigma \mathrm{ni}$

$\mathrm{Ni}$ = number of emerged seedlings per day;

$\mathrm{Ti}=$ evaluation time (days).

At 51 DAE the following assessments were carried out:

d) Number of leaves per plant ( $n$ o plant ${ }^{-1}$ ): obtained by counting the number of leaves on each plant;

e) Stem diameter $(\mathrm{mm})$ : measured at the height of the plant's lap by means of readings using a digital caliper (Clarke, $150 \mathrm{~mm}$ ), with a degree of accuracy of $\pm 0.01 \mathrm{~mm}$;

f) Plant height $(\mathrm{cm})$ : determined from the soil surface to the insertion of the last leaf with a millimeter ruler;

g) Root system volume $\left(\mathrm{cm}^{3}\right.$ plant $\left.{ }^{-1}\right)$ : determined by the water displacement method using a $100 \mathrm{~mL}$ beaker graduated in milliliters $(\mathrm{mL})$ with an accuracy of $\pm 1.0 \mathrm{~mL}$;

The plants were sectioned into leaves, stem, and root to determine:

h) Leaves dry matter (g plant ${ }^{-1}$ );

i) Stem dry matter (g plant ${ }^{-1}$ );

j) Root system dry matter (g plant $\left.{ }^{-1}\right)$;

k) Shoot dry matter $\left(g\right.$ plant $\left.^{-1}\right)$ : estimated by the sum between the leaves dry matter and stem dry matter;

I) Total dry matter (g plant $\left.{ }^{-1}\right)$ : estimated by the sum of the shoot dry matter and root system dry matter;

$\mathrm{m})$ Leaf area $\left(\mathrm{dm}^{2}\right.$ plant $\left.{ }^{-1}\right)$ : determined following the methodology proposed by Benincasa (2003). Ten leaf discs of the known area were removed from each experimental unit, which was considered as the leaf area of the sample (LAS). Then, the sample dry matter (SDM) and the leaves dry matter (LDM) were determined after drying at 65 으 for 72 hours. Leaf area (LA) was estimated with the following equation:

$\mathrm{LA}=\frac{\mathrm{LAS} \times(\mathrm{LDM}+\mathrm{SDM})}{\mathrm{SDM}}$

n) Root system density $\left(\mathrm{g} \mathrm{cm}^{-3}\right)$ : estimated by dividing the root system dry matter by root system volume;

o) Shoot-root ratio $\left(\mathrm{g} \mathrm{g}^{-1}\right)$ : estimated by dividing the shoot dry matter by root system dry matter; p) leaf area ratio $\left(\mathrm{dm}^{2} \mathrm{~g}^{-1}\right)$ : estimated by dividing the leaf area by total dry matter (Benincasa, 2003);

q) Specific leaf area $\left(\mathrm{dm}^{2} \mathrm{~g}^{-1}\right)$ : estimated by dividing the leaf area by the leaves dry matter (Benincasa, 2003);

r) Leaf matter ratio $\left(\mathrm{g} \mathrm{g}^{-1}\right)$ : obtained by dividing the leaves dry matter by the total dry matter (Benincasa, 2003).

\section{Statistical analysis}

The data were submitted to analyses of normality and homoscedasticity. These assumptions were not met in any of the evaluated variables. Therefore, the data were transformed into $\sqrt{x}$. After analysis with transformed data, conformity with normality and homoscedasticity was verified, however, the data were presented in the original form. Variance analysis was performed, and the significance of the mean squares obtained was tested by the F-test at the $5 \%$ probability level. The means were compared by the LSD test, at the $5 \%$ probability level.

\section{Conclusion}

Seed size does not influence the emergence rate of soybean seedlings; however, the soybean seeds with $7.0 \mathrm{~mm}$ produced plants with higher stem and shoot dry matter and root system volume. The soybean sowing at $4.0 \mathrm{~cm}$ depth results in the best plant development in sandy soil. The size of the soybean seed does not influence the determination of the sowing depth in sandy soils.

\section{Acknowledgments}

The authors express their gratitude to CAPES (Coordination for the Improvement of Higher Education Personnel) for the granting of PND/Capes scholarships, Mato Grosso do Sul State University for the logistical support.

\section{References}

Aisenberg GR, Pedó T, Aumonde TZ, Vilela FA (2014) Vigor e desempenho de crescimento inicial de plantas de soja: efeito da profundidade de semeadura. Enc Biosfera. 10(18):3080-3091.

Alcântara Neto F, Gravina GA, Monteiro MMS, Morais FB, Petter FA, Albuquerque JAA (2011) Análise de trilha do rendimento de grãos de soja na microrregião do Alto Médio Gurguéia. Comunicata Sci. 2(2):107-112.

Reis Barbosa CZ, Smiderle OJ, Alves JMA, Vilarinho AA, Sediyama T (2010) Qualidade de sementes de soja BRS Tracajá, colhidas em Roraima em função do tamanho no armazenamento. Ciênc Agron. 41(1): 73-80.

Benincasa MMP (2003) Análise de crescimento de plantas (noções básicas). Jaboticabal: Funep.

Bezerra ARG, Soares MMS, Sediyama T (2016) Tamanho e Vigor Da Semente. Em: Sedyama, T. Produtividade da soja. Londrina: Mecenas.

Camozzato VA, Peske ST, Possenti JC, Mendes AS (2009) Desempenho de cultivares de soja em Função do tamanho das sementes. Rev Bras Sementes. 31(1):288-292.

Casaroli D, Fagan EB, Simon J, Medeiros SP, Manfron PA, Neto DD, Lier QJV, Müller L, Martin TN (2007) Radiação Solar e aspectos fisiológicos na cultura de soja - uma revisão. Rev FZVA. 14(2):102-120. 
EMBRAPA. Empresa Brasileira de Pesquisa Agropecuária (2009) Manual de análises químicas de solos, plantas e fertilizantes. Brasília: Embrapa Solos, Embrapa Informática Tecnológica.

EMBRAPA. Empresa Brasileira de Pesquisa Agropecuária (2011) Tecnologias de producao de soja-Regiao Central do Brasil-2012/2013. Londrina: Embrapa Soja.

FAO. Food And Agriculture Organization (2017) Technology of production of edible flours and protein products from soybeans. Chapter $1 . \quad$ Available in: http://www.fao.org/docrep/t0532e/t0532e02.htm, accessed in: 23/01/2017.

Kering MK, Zhang B (2015) Effect of Priming and Seed Size on Germination and Emergence of Six Food - Type Soybean Varieties. Int J Agron. 2015:1-6.

Kopper AC, Malavasi MM, Malavasi UC (2010) Infuência da temperatura e do substrato na germinação de sementes de Cariniana estrellensis (Raddi) Kuntze. Rev Bras Sementes. 32(2):160-165.

Labouriau LG (1983) A germinação das sementes. Washington: Secretaria Geral da Organização dos Estados Americanos.

Maguire JD (1962) Speed of germination aid in selection and evaluation for seedling emergence and vigor. Crop Sci. 2(2):176-177.

Mandal SM, Chakraborty D, Gupta K (2008) Seed size variation: influence on germination and subsequent seedling performance in Hyptissuaveolens (Lamiaceae). Res J Seed Sci. 1(1):26-33.

Modolo AJ, Trogello E, Nunes AL, Fernandes HC, Silveira JCM, Dambros MP (2010) Efeito de cargas aplicadas e profundidades de semeadura no desenvolvimento da cultura do feijão em sistema de plantio direto. Ciênc Agrotec. 34(3):739-745.

Pádua GP, Zito RK, Arantes NE, França Neto JB (2010) Influência do tamanho da semente na qualidade fisiológica e na produtividade da cultura da soja. Rev Bras Sementes. 32(3):009-016.
Piccinin GG, Dan LGM, Ricci TT, Braccini AL, Barbosa MC, Moreano TB, Neto AH, Bazo GL (2012) Relação entre o tamanho e a qualidade Fisiológica e sanitária de sementes de soja. Rev Agrar. 5(15):20-28.

Prado RM, Coan O, Villar MLP (2002) Compressão do solo e profundidade de semeadura na emergência e no crescimento inicial da cultura do milho (Zea Mays L.). Rev Cient Eletrônica Agron. 2:1-6.

Roy SKS, Hamid A, Miah MG, Hashem A (1996) Seed size variation and its effects on germination and seedling vigour in rice. J Agron Crop Sci. 176(2):79-82.

Souza NM, Weirich Neto PH (2015) Test for alternative indicator of soybean sowing depth. Eng Agríc. 35(1):128133.

Tillmann MAA, Piana Z, Cavariani C, Minami K (1994) Efeito da profundidade de semeadura na emergência de plântulas de tomate (Lycopersicon esculentum Mill.). Sci Agric. 51(2):260-263.

Pacheco LP, Pires FR, Monteiro FP, Procopio SO, Assis RL, Petter FA (2010) Profundidade de semeadura e crescimento inicial de espécies forrageiras utilizadas para cobertura do solo. Ciênc Agrotec. 34(5):1211-1218.

Vinhal-Freitas IC, Junior JEG, Segundo JP, Vilarinho MS (2011) Germinação e vigor de sementes de soja classificadas em diferentes tamanhos. Agropecu Tec. 32(1):108-114.

Zuo Q, Kuai J, Zhao L, Hu Z, Wu J, Zhou G (2017) The effect of sowing depth and soil compaction on the growth and yield of rape seed in rice straw returning field. Field Crop Res. 203:47 -54.

Zuffo AM, Zuffo Junior JM, Carvalho RM, Zambiazzi EV, Guilherme SR, Borges IMM, Ribeiro FO, Santos AS, Fonseca WL, Sousa TO (2016) Emergence and early growth of Baru seedlings on different substrates. Afr J Agric Res. 11(28): 2481-2485. 